International Journal of Child, Youth and Family Studies (2011) 2.1: 172-196

\title{
RELATING RISK AND PROTECTIVE FACTORS TO YOUTH REOFFENDING: A TWO-YEAR FOLLOW-UP
}

\section{Leslie D. MacRae, Lorne D. Bertrand, Joanne J. Paetsch, and Joseph P. Hornick}

\begin{abstract}
This article presents findings of a retrospective longitudinal study of youth reoffending in Calgary, Alberta, Canada. Increasingly, the examination of risk and protective factors in the youth reoffending literature is grouped into five general domains: individual, family, peer, school, and community. For purposes of the present study, data on each of these factors were obtained from interviews and probation file reviews for a sample of 123 youth who had various levels of involvement in the youth justice system. These baseline data were collected from July 2006 to July 2007. Reoffending was tracked for two years following the interview using police contact data. Descriptive findings indicated that, overall, youth who possessed risk factors in each domain had a higher average rate of reoffending. Stepwise linear regression analysis revealed that in the individual domain, a history of purchasing illegal drugs, stealing a car or motorcycle, and committing an assault with a weapon, as well as a diagnosis of ADD/ADHD, were significantly related to the extent of reoffending. In the peer domain, gang affiliation was significant. In the community domain, the presence of gangs in the community was significant. None of the predictors in the family or school domains were significant. Implications for future Canadian research are discussed.
\end{abstract}

Key Words: youth, reoffending, risk factors, longitudinal study

Acknowledgement: The authors would like to acknowledge the City of Calgary and the Alberta Law Foundation for funding this project.

Leslie D. MacRae, M.A. is the Coordinator of Alberta-Based Research Projects at Canadian Research Institute for Law and the Family.

Lorne D. Bertrand, Ph.D. is the Senior Research Associate at Canadian Research Institute for Law and the Family.

Joanne J. Paetsch, B.A. is a Research Associate and Administrator at Canadian Research Institute for Law and the Family.

Joseph P. Hornick, Ph.D. is the Executive Director at Canadian Research Institute for Law and the Family.

Contact information for authors: Canadian Research Institute for Law and the Family, Suite 510, 1816 Crowchild Trail, NW, Calgary AB, Canada, T2M 3Y7, Phone: 403-216-0340, Email: crilf@ucalgary.ca 
International Journal of Child, Youth and Family Studies (2011) 2.1: 172-196

Youth crime in Canada has undergone considerable scrutiny in the past decade, both in the media and in terms of policy. In 2003, the Youth Criminal Justice Act (YCJA) replaced the Young Offenders Act as Canada's legislative response to youth offending, the objectives being to restrict the use of the courts by diverting minor cases and facilitating reintegration and rehabilitation. It also had the goal of reducing the incarceration rate by providing more meaningful and effective responses for serious and violent young offenders (Department of Justice Canada, n.d.).

Studies examining the impact of the YJCA (e.g., DeGusti, 2008; Bala, Carrington, \& Roberts, 2009) report that, though the number of youth charged, convicted, and sentenced decreased, particularly those involved in minor offences, practice based on the YCJA continues to struggle in effectively addressing the complex needs of repeat offenders. Recent reports from British Columbia (British Columbia Representative for Children and Youth \& Provincial Health Officer, 2009), Nova Scotia (Nunn, 2006), and Ontario (McMurtry \& Curling, 2008) reveal the significant impact that youth violence and youth offending continue to have in Canada, prompting a need for further development of effective responses to this particular group of young offenders. Among the recommendations in Alberta's Crime Reduction and Safe Communities Task Force Report (2007) was the need to understand the characteristics that distinguish young people who engage in criminal behaviour from those who do not - the factors that "buffer young people from risks and promote positive youth development” (p. 34). Though studies from the United States, the United Kingdom, and Australia provide a solid foundation for research in this area, there is a demonstrable need for Canadian research on identifying risk and protective factors for youth offending and reoffending,

\section{Risk Factors and Youth Reoffending}

Increasingly, the examination of risk and protective factors in the youth offending literature is grouped into five general domains:

- Individual factors, which include demographic characteristics (age, gender, socioeconomic status), aggression and impulsivity, substance abuse, and mental and emotional health;

- $\quad$ Family factors, which include family function and stability;

- $\quad$ Peer factors, which include peer associations, gang involvement, and social experiences;

- $\quad$ School factors, which include school experiences, success, and attachment; and

- Community factors, which include community safety, degree of organization, and attachment.

Individual Factors. The examination of individual demographic factors, such as gender, ethnicity, and socio-economic status has a long history in the youth offending literature. Gender is consistently examined in studies of youth criminality, with males commonly associated with offending and reoffending. However, the advent of specialized studies on criminal trajectories and life course persistent offending reflects that females are increasingly represented among 
offender typologies (Carr \& Vandiver, 2001; Happanen, Britton, \& Croisdale, 2007; Howell, 2003; Jennings, Moldonado-Molina, \& Komro, 2010). Longitudinal studies suggest that a different set of factors predict male and female chronic reoffending (Sharkey, Furlong, Jimerson, \& O’Brien, 2003; Trulson, Marquart, Mullings, \& Caeti, 2005; Tyler, Johnson, \& Brownridge, 2008). Along with gender, ethnicity and socio-economic status are common factors predicting offending and reoffending among youth, with both poverty and ethnic minority status being significantly linked to youth reoffending (Benda \& Tollett, 1999; Livingston, Stewart, Allard, \& Ogilvie, 2008; Trulson et al., 2005). However, similar to gender, studies examining differences between minor reoffending and chronic reoffending have raised questions regarding the ability to distinguish between these two groups on the basis of socio-economic status and ethnicity (Mullis et al., 2005).

Howell (2009) suggests that the impact of ethnicity and socio-economic status is best understood if examined within a developmental context. Other individual factors such as mental and emotional health and substance abuse are important. Howell (2009) suggests that approximately $65 \%$ to $70 \%$ of youth in juvenile correctional facilities in the United States experience mental health and/or substance use disorders, one-quarter of whom have disorders that significantly impair their ability to function. A Toronto study of criminal trajectories (Day, Bev, Theodor, Rosenthal, \& Duchesne, 2008) revealed that $82 \%$ of the youth studied met the criteria for at least one psychiatric disorder. Specifically, Attention Deficit or Attention Deficit Hyperactivity Disorder (ADD/ADHD) and Oppositional Defiant Disorder (Mullis et al., 2005; Putnins, 2005), as well as neuropsychological conditions such as Fetal Alcohol Spectrum Disorder (Turner, Hartman, \& Bishop, 2007), are linked particularly to chronic reoffending, with substance abuse being consistently linked with a risk to reoffend (Howell, 2009; Denning \& Homel, 2008; Putnins, 2005; Sharkey et al., 2003).

Finally, among the most potent predictors of future offending is past delinquent or antisocial behaviour, and this is particularly true of serious repeat offenders. Studies have demonstrated that repeat offenders habitually commit a number of different antisocial acts, often having previous contact with the justice system and well-documented behavioural issues (Benda \& Tollett, 1999; Mullis et al., 2005).

Family Factors. There is a substantial body of literature suggesting that poor family management and supervision, family breakdown, parental separation, and physical abuse or neglect are significant predictors of reoffending among youth. A number of studies have shown that the experience of family violence is common among youth who are chronic or persistent offenders (Arnull et al., 2005; Lemmon, 2006; MacRae, Bertrand, Paetsch, \& Hornick, 2008). Recent literature from Australia (Stewart, Livingston, \& Dennison, 2008) reveals that youth who experience maltreatment during adolescence are more likely to reoffend than those who experience maltreatment prior to adolescence.

Factors related to family disruption and breakdown are also linked to reoffending. MacRae et al. (2008) report that serious habitual offenders are more likely to have family histories of divorce, separation, or never married parents compared with one-time offenders or

Canadian Research Perspectives for Youth at Risk for Serious and 
youth who had been diverted from the justice system after contact with police. Jennings and colleagues (2010) found that not living in a birth parent household increased the likelihood of being on a delinquent trajectory. Arnull et al. (2005), in their large-scale study of persistent offenders in England and Wales, revealed that one of the most telling risk factors for reoffending was a history of family disruption. Ward and Day's (2010) study suggests that family disruption, specifically in childhood, increases the likelihood of youth following a moderate course of offending, and in adolescence, a low course of offending. Conversely, Carr and Vandiver's (2001) study of protective factors and recidivism revealed that those who do not reoffend are more likely to have a higher average number of familial protective factors (e.g., structure, support, and supervision).

Ward and Day (2010) also report that contact with the child welfare system in childhood and alternative care in adolescence increased the likelihood that a youth would follow a higher offending trajectory, which is in line with the findings of a recent study of youth justice outcomes for children in care (British Columbia Representative for Children and Youth \& British Columbia Provincial Health Officer, 2009). Similar findings can be found in U.S. studies regarding the relationship between child welfare placements and future offending. One U.S. longitudinal study found that youth in care, particularly those who had experienced familial mistreatment, were more likely to reoffend than youth who were not in care (Ryan, 2006). Ryan, Hernandez, and Herz's (2007) study of developmental trajectories of male adolescents reported that leaving foster care and placement instability were among the most important predictors of reoffending. Howell's (2009) developmental model of serious delinquency reinforces the notion that a child or youth having a non-intact family (i.e., not living with biological parents) is an important predictor.

Other important family factors include living arrangements and parental support or supervision. Howell's (2009) model of serious delinquency suggests that not residing in a home with two parents increases the risk of serious delinquency. Jennings and colleagues (2010), in their study of criminal trajectories, suggest that spending greater amounts of time without parental supervision increased the likelihood of a youth being on a delinquent trajectory. A number of studies have also shown that poor family attachment (e.g., running away from home, not residing with parents) is more common among those youth who persistently reoffend (MacRae et al., 2008; Tyler et al., 2008).

Peer Factors. Peer factors, including gang affiliation and association with deviant and often older peers, have long been discussed as contributing factors to youth engagement in delinquent behaviour, and more recently as a factor predicting reoffending (Arnull et al., 2005; Chung, Hill, Hawkins, Gilchrist, \& Nagin, 2002; Denning \& Homel, 2008; Howell, 2009; Johnson, Simons, \& Conger, 2004; MacRae et al., 2008; Mullis et al., 2005; Sharkey et al., 2003). In recent work examining peer influence within a developmental context, Howell (2009) suggests that gang membership and affiliation, as well as negative peer influences, may have more of an impact in adolescence. Johnson and colleagues (2004) suggest that for youth with a history of involvement in the justice system, having deviant peer associations, particularly as the youth gets older, is a significant predictor for persistent reoffending. This speaks to the possible 
role of the justice system (especially custodial) in exposing youth to other negative peers, and the subsequent effect such encounters can have on future behaviour. In a related way, gang affiliation or involvement has also been shown to have a significant influence on offending, with studies demonstrating that youth who are persistent reoffenders are more likely to have ties to gangs (Benda \& Tollett, 1999; Howell, 2003; MacRae et al., 2008; Trulson et al., 2005). Benda and Tollett (1999) suggest that, although gang membership is a significant predictor of continued offending among serious and persistent youth offenders in particular, the frequency, intensity, duration, and priority of gang membership, as well as the type of gang, should be considered in order for gang affiliation to be a more accurate predictor.

It is important to note the available findings related to the protective influence of positive peer or social relations. In comparing non-repeat offenders to repeat offenders, Carr and Vandiver (2001) reported that positive peer selection acted as a protective factor. MacRae et al.'s (2008) Calgary study of youth offenders found that those youth who had a record of chronic and serious habitual offending were markedly less likely to report involvement in organized afterschool activities, adult-coached sports, organized non-sport activities, and clubs with adult leadership. This compares to the minor offenders in the sample who were more likely to associate with prosocial peers and commonly participated in sports and groups in their spare time.

School Factors. School is a key domain to consider in youth development, one where early signs of future antisocial behaviour may be evident. Risk factors in the school domain include low investment and commitment to school, early academic struggle and/or failure, problem behaviour in school, poor attitude, and truancy. Research has suggested that youth who proceed to serious offending experience significant disciplinary, attainment, and learning challenges in school (Arnull et al., 2005; MacRae et al., 2008; Mullis et al., 2005). As discussed previously, diagnoses of ADD/ADHD and learning exceptionalities are common among reoffending youth (Putnins, 2005), which also has a significant impact on school investment and success. Further, truancy has been identified as a common concern among reoffending youth (Mullis et al., 2005; MacRae et al., 2008). Frequent school transitions or lack of school stability was observed by Mullis and colleagues (2005) as a common experience among persistent reoffenders.

Community Factors. Finally, community factors such as neighbourhood disorganization, safety, and availability of drugs and weapons have a significant impact on a youth's offending behaviour. A number of studies in the past decade (Benda \& Tollett, 1999; Chung et al., 2002; McMurtry \& Curling, 2008) have examined the impact of these community influences, finding that youth who live in disorganized, unsafe neighbourhoods, particularly where drugs or weapons are readily available, are more likely to become chronic offenders. Moreover, not surprisingly, carrying a weapon in the community is associated with serious reoffending (Benda \& Tollett, 1999; MacRae et al., 2008). A recent study by Grunwald, Lockwood, Harris, and Mennis (2009) reported that neighbourhood-level factors such as concentrated disadvantage and social capital have a differential impact on reoffending types, having the most significant impact on drug offence recidivism. Further, as both Patterson, Reid, and Dishion (1992) and Turner and 
International Journal of Child, Youth and Family Studies (2011) 2.1: 172-196

colleagues (2007) note, community influences are often mitigated by the presence of a number of other factors that tend to decrease the impact of negative influences present in the community. Patterson and colleagues (1992) suggest the effect of violent or crime-ridden neighbourhoods is mitigated by the presence of parents who effectively supervise and discipline their children, as opposed to children who experience poor parental management. Turner and colleagues (2007) suggest that disadvantaged neighbourhoods often interact with other risk factors (e.g., neuropsychological deficits and family disadvantage) to place a child at increased risk for serious reoffending.

\section{Method}

\section{Sample}

Data for this study was generated from a three-year study of high-risk youth in Calgary (MacRae, Bertrand, Paetsch, Hornick, \& DeGusti, 2009). In this study, a cohort of 123 youth was classified into four different study groups depending on levels of involvement in the youth justice system. The study groups were:

1. Gateway clients under extrajudicial measures $(n=20)$;

2. one-time offenders $(n=42)$;

3. chronic offenders $(n=41)$; and

4. serious habitual offenders (SHOs) $(n=20)$.

Gateway is a pre-charge extrajudicial measures program under the Youth Criminal Justice Act (YCJA) that operates in all eight police districts in Calgary. Under this program, youth are diverted by the police from the traditional youth justice system to over 25 community agencies that have agreed to offer services to youth. Youth are referred to this program for offences ranging from theft under $\$ 5,000$, to mischief, break and enter, and minor assault. Gateway is a partnership of City of Calgary Community and Neighbourhood Services and the Calgary Police Service.

One-time offenders include youth who have one substantive (i.e., Criminal Code) offence or incident under the Controlled Drugs and Substances Act of which he or she has been found guilty in youth court (with no subsequent charges pending). Chronic offenders include youth who have five or more substantive offences or incidents of which they have been found guilty (not including SHOs). An incident was defined as all charges pertaining to the same person and having the same date of offence. Administration of justice incidents (e.g., breaches, failures to appear) were not counted as substantive incidents.

SHOs included youth involved in the Calgary Police Service Serious Habitual Offender Program (SHOP), the goal of which is to identify youth at risk of a career of crime. The program provides access to resources in order for these offenders to become successful members of society. Referrals to SHOP are made by various agencies, and each referring agency is required to complete an intake form providing information on historical risk factors (e.g., violent acts or 
offences, exposure to violence), social and contextual risk factors (e.g., peer delinquency, parental management, personal support, etc.), and individual risk factors (e.g., emotional difficulties, attitudes, risk taking, substance use, etc.). Referral information is received by the Calgary Police Service SHOP unit, who check the youth's criminal history. If appropriate for the program, the youth's information is forwarded to the Multidisciplinary Resource Team (MDRT), who review and assess the youth's records and determine whether he or she is appropriate for SHOP. Youth who are targeted by the program are profiled, with responses based on these profiles being developed to support the youth's successful reintegration. These youth are regularly monitored by the Calgary Police Service.

Gateway participants were identified and recruited through the Gateway program. Onetime and chronic offenders were identified through the City of Calgary Youth Probation Services. SHOs were identified with the help of the City of Calgary Youth Probation Services and the Calgary Police Service. Informed consent was obtained from all youth participating in the study, and parental consent was obtained for youth under age 16.

For the purpose of this study, to determine which risk factors differentiate youth who reoffend from those who do not and the extent of reoffending behaviour, the four original study groups were analyzed together as the number of subjects in each group was not sufficient to examine between-group differences in risk factors. The majority of the sample was male (82.9\%). At the time of data collection, the mean age of the youth was 16.5 years. In terms of ethnicity, three-quarters of the sample were identified as Caucasian (74\%), with smaller proportions identifying themselves as Native (8.9\%), Asian (4.9\%), Metis (3.3\%), MiddleEastern (2.4\%), Mulatto (2.4\%), Hispanic (2.4\%), and African (2.4\%). The substantial majority of youth $(93.5 \%)$ were born in Canada.

\section{Measures}

The original study utilized a number of methodologies to develop a profile of youth offenders in Calgary. Most relevant to this examination of youth reoffending are the data collected from interviews and probation file reviews. Life history interviews were conducted with all 123 participants from July 12, 2006 to July 18, 2007. The interview schedule was developed by the researchers, with questions covering seven main topic areas: basic facts (i.e., demographic, familial); community (i.e., community characteristics, feelings of safety); school (i.e., school status, experience); social life (i.e., friends, activities, delinquency); offending history (i.e., contact with the criminal justice system); gangs (i.e., knowledge and experience of gangs in Calgary); and future plans (i.e., goals). Interviews were conducted in person with the exception of Gateway participants, who were interviewed by telephone. Participants were each paid $\$ 20$.

Probation file reviews were conducted for each youth interviewed for the study, with the exception of the Gateway sample (who were not under the jurisdiction of City of Calgary Youth Probation) and a small number of youth in other groups whose probation files could not be accessed. The file review measure provided supplemental and validating data to the interview. A 
International Journal of Child, Youth and Family Studies (2011) 2.1: 172-196

probation file review form was developed following a preliminary examination of probation files. The form included demographic, familial, social, and offending information. File reviews were conducted at Youth Probation Offices. Researchers examined each probation file and filled out the electronic review form with the necessary information. Conviction data was obtained from the Justice Online Information Network (JOIN) to distinguish between the one-time and chronic offender groups.

For the purposes of the offender profiles, analysis of the interview and file review data was conducted descriptively by offender type, with the goal of establishing defining characteristics for each group of offenders. A number of social, individual, and historical factors explored the differences among the four groups of offenders, covering eight main areas: demographic characteristics; family characteristics; educational experience; social life; community characteristics; self-reported delinquency; knowledge of gangs; and justice system involvement.

Data on the reoffending patterns of the 123 youth interviewed for this study from the date of their interview through October 31, 2008 was obtained from the Calgary Police Service's Police Information Management System (PIMS). Data obtained from PIMS were for chargeable incidents, which refer to contacts between offenders and the police where there was sufficient evidence for an information to be laid, whether or not an offender was actually charged. Only substantive incidents are included in the database and therefore administrative offences (e.g., breaches) are excluded.

Initial interviews were conducted during the period from July 12, 2006 to July 18, 2007; thus, the length of time available for youth to reoffend from the date of their interview to October 31, 2008 varied across participants in the study. In order to compensate for this artefact, data were initially examined according to three reoffending time periods: within 12 months after the interview; within 12 to 18 months after the interview; and within 18 to 24 months after the interview. All 123 youth were in the study for a sufficient period of time to be eligible to have data in the 12 months after the interview and 12 to 18 months after the interview time intervals. A total of 89 youth had a sufficient time period following their interview to potentially have reoffending data in the 18 to 24 months after the interview time interval.

\section{Results}

A total of 58 participants (47.2\%) reoffended at least once during the time period between their interview and October 31, 2008. For the youth who reoffended, the number of reoffences ranged from 1 to 24 (mean $=4.55$, standard deviation $=4.84$ ).

\section{Factors Associated with Reoffending}

The relationship between factors relevant to the five domains identified in the literature (i.e., individual, family, peer group, school, and community) and youth reoffending was examined using a series of forward stepwise linear regression analyses with the number of 
reoffences as the dependent measure and a series of binary predictor variables within each domain serving as independent variables. This procedure allowed the identification of the predictors within each of the domains that accounted for the greatest proportion of variance within the dependent variable. Predictor variables were obtained from either the young offender interview or the youth probation file review.

Individual Factor Domain. Several potential risk factors for reoffending classified within the individual domain were examined. These factors fell into five general categories: personal characteristics; drug- and alcohol-related behaviour; property-related delinquency; person-related delinquency; and mental health characteristics. Table 1 presents the average number of reoffences for three personal characteristics falling within this domain. There was a trend for males to exhibit a higher number of reoffences than females and for non-Caucasian youth to reoffend to a greater extent than Caucasian youth. However, when these three variables were entered into a stepwise regression, none emerged as being significant predictors for reoffending.

TABLE 1

MEAN NUMBER OF REOFFENCES SINCE YOUTH OFFENDER INTERVIEW BY PERSONAL CHARACTERISTICS

\begin{tabular}{|l|c|c|c||}
\hline \multicolumn{1}{|c|}{ Personal Characteristics } & \multicolumn{2}{c|}{ Number of Reoffences } \\
\cline { 2 - 4 } & Mean & SD & n \\
\hline \hline Gender & & & 21 \\
$\quad$ Female & 0.95 & 1.43 & 102 \\
Male & 2.39 & 4.33 & \\
\hline Ethnicity & & & 91 \\
$\quad$ Caucasian & 1.82 & 3.92 & 32 \\
$\quad$ Other & 3.06 & 4.22 & \\
Employment Status at Time of Interview & & & 59 \\
Employed & 2.22 & 3.57 & 64 \\
$\quad$ Not Employed & 2.08 & 4.41 & \\
\hline \hline
\end{tabular}

a “Other” includes Native/Métis $(n=15)$, Hispanic $(n=3)$, African $(n=2)$, Mulatto $(n=3)$, Asian ( $n=6)$, and Middle Eastern $(n=3)$.

Sources of data: Youth Offender Interview, Youth Probation File Review and Police Information Management System.

Table 2 presents the relationship between alcohol and drug risk factors and reoffending. The substantial majority of all youth in the study reported that they had consumed five or more alcoholic drinks on at least one occasion (91.9\%) and had ever used an illegal drug (87.8\%). Three-quarters of the youth had bought illegal drugs (74.8\%) and over one-half (56.1\%) had sold 
drugs. When these four predictors for reoffending were included in a stepwise regression, the only variable entered into the regression equation was having bought illegal drugs (Adjusted $R^{2}=$ 0.04 , Beta $=0.21, t(121)=2.40, p<.05)$. Youth who stated they had bought illegal drugs prior to their interview were likely to have a higher number of reoffences following the interview than youth who had never bought illegal drugs.

TABLE 2

MEAN NUMBER OF REOFFENCES SINCE YOUTH OFFENDER INTERVIEW BY DRUG AND ALCOHOL RELATED BEHAVIOUR

\begin{tabular}{|c|c|c|c|}
\hline \multirow{2}{*}{ Behaviour } & \multicolumn{3}{|c|}{ Number of Reoffences } \\
\hline & Mean & $S D$ & $n$ \\
\hline \multicolumn{4}{|l|}{$\begin{array}{l}\text { Had Five or More Alcoholic Drinks on One } \\
\text { Occasion }\end{array}$} \\
\hline No & 0.50 & 1.27 & 10 \\
\hline Yes & 2.29 & 4.14 & 113 \\
\hline \multicolumn{4}{|l|}{ Ever Used Illegal Drugs } \\
\hline No & 0.27 & 1.03 & 15 \\
\hline Yes & 2.41 & 4.21 & 108 \\
\hline \multicolumn{4}{|l|}{ Ever Bought Illegal Drugs } \\
\hline No & 0.68 & 1.35 & 31 \\
\hline Yes & 2.64 & 4.48 & 92 \\
\hline \multicolumn{4}{|l|}{ Ever Sold Illegal Drugs } \\
\hline No & 1.50 & 3.26 & 54 \\
\hline Yes & 2.65 & 4.48 & 69 \\
\hline
\end{tabular}

Sources of data: Youth Offender Interview and Police Information Management System.

Table 3 presents the relationship between engaging in several property-related delinquent behaviours at the time of the initial interview and the extent of subsequent reoffending. For all types of delinquency, there was a trend for youth who reported having engaged in property crimes to have a greater number of reoffences. When these eight predictors of reoffending were entered into a stepwise regression, the only variable that emerged as a significant predictor of the extent of reoffending was having stolen a car or motorcycle (Adjusted $R^{2}=0.10$, Beta $=0.33$, $t(119)=3.85, p<.001)$. Youth who had stolen a car or motorcycle prior to their interview were more likely to have a greater number of reoffences following the interview than youth who had never engaged in this delinquent behaviour. 
TABLE 3

\section{MEAN NUMBER OF REOFFENCES SINCE YOUTH OFFENDER INTERVIEW BY EVER ENGAGING IN PROPERTY-RELATED DELINQUENT BEHAVIOUR}

\begin{tabular}{|c|c|c|c|}
\hline \multirow{2}{*}{ Delinquent Behaviour } & \multicolumn{3}{|c|}{ Number of Reoffences } \\
\hline & Mean & $S D$ & $n$ \\
\hline $\begin{array}{l}\text { Damaged/Destroyed Property on Purpose } \\
\text { No } \\
\text { Yes }\end{array}$ & $\begin{array}{l}1.79 \\
2.33\end{array}$ & $\begin{array}{l}3.07 \\
4.43\end{array}$ & $\begin{array}{l}42 \\
81\end{array}$ \\
\hline $\begin{array}{l}\text { Broken into a House } \\
\text { No } \\
\text { Yes }\end{array}$ & $\begin{array}{l}1.25 \\
3.25\end{array}$ & $\begin{array}{l}2.76 \\
4.97\end{array}$ & $\begin{array}{l}68 \\
55\end{array}$ \\
\hline $\begin{array}{l}\text { Stolen Something Worth Less than } \$ 50 \\
\text { No } \\
\text { Yes }\end{array}$ & $\begin{array}{l}1.44 \\
2.37\end{array}$ & $\begin{array}{l}2.72 \\
4.39\end{array}$ & $\begin{array}{l}39 \\
83\end{array}$ \\
\hline $\begin{array}{l}\text { Stolen Something Worth More than } \$ 50 \\
\text { No } \\
\text { Yes }\end{array}$ & $\begin{array}{l}1.50 \\
2.38\end{array}$ & $\begin{array}{l}4.00 \\
3.92\end{array}$ & $\begin{array}{l}42 \\
80\end{array}$ \\
\hline $\begin{array}{l}\text { Stolen Car or Motorcycle } \\
\text { No } \\
\text { Yes }\end{array}$ & $\begin{array}{l}0.84 \\
3.47\end{array}$ & $\begin{array}{l}1.67 \\
5.18\end{array}$ & $\begin{array}{l}64 \\
57\end{array}$ \\
\hline $\begin{array}{l}\text { Stolen Something with a Group of Friends } \\
\text { No } \\
\text { Yes }\end{array}$ & $\begin{array}{l}1.72 \\
2.28\end{array}$ & $\begin{array}{l}2.96 \\
4.43 \\
\end{array}$ & $\begin{array}{l}43 \\
78 \\
\end{array}$ \\
\hline $\begin{array}{l}\text { Ridden Calgary Transit without Valid Ticket } \\
\text { No } \\
\text { Yes }\end{array}$ & $\begin{array}{l}0.92 \\
2.44\end{array}$ & $\begin{array}{l}1.64 \\
4.36\end{array}$ & $\begin{array}{l}24 \\
99\end{array}$ \\
\hline $\begin{array}{l}\text { Damaged/Vandalized/Tagged Calgary Transit } \\
\text { Property } \\
\text { No } \\
\text { Yes }\end{array}$ & $\begin{array}{l}2.04 \\
2.45\end{array}$ & $\begin{array}{l}3.65 \\
5.01\end{array}$ & $\begin{array}{l}92 \\
31\end{array}$ \\
\hline
\end{tabular}

Sources of data: Youth Offender Interview and Police Information Management System.

Table 4 presents the relationship between engaging in several person-related delinquent behaviours at the time of the initial interview and subsequent reoffending. For all behaviours, there was a tendency for youth who reported engaging in person offending to have a higher average number of reoffences. These seven predictors of reoffending were included in a stepwise 
regression procedure with the number of reoffences as the dependent measure. The only predictor significantly associated with the number of reoffences was having assaulted someone with a weapon (Adjusted $R^{2}=0.08$, Beta $=0.30, t(105)=3.21, p<.01$ ). This result indicated that youth who had ever assaulted someone with a weapon prior to their interview were likely to have a greater number of reoffences following the interview than youth who had never assaulted someone with a weapon.

TABLE 4

\section{MEAN NUMBER OF REOFFENCES SINCE YOUTH OFFENDER INTERVIEW BY EVER ENGAGING IN PERSON-RELATED DELINQUENT BEHAVIOUR}

\begin{tabular}{|c|c|c|c|}
\hline \multirow{2}{*}{ Delinquent Behaviour } & \multicolumn{3}{|c|}{ Number of Reoffences } \\
\hline & Mean & $S D$ & $n$ \\
\hline \multicolumn{4}{|l|}{$\begin{array}{l}\text { Taken/Tried to Take Something by } \\
\text { Force/Threat of Force }\end{array}$} \\
\hline No & 1.98 & 4.40 & 60 \\
\hline Yes & 2.47 & 3.71 & 49 \\
\hline \multicolumn{4}{|l|}{$\begin{array}{l}\text { Harassed, Threatened, or Bullied Someone on } \\
\text { Calgary Transit }\end{array}$} \\
\hline No & 1.74 & 3.35 & 88 \\
\hline Yes & 3.24 & 5.33 & 34 \\
\hline \multicolumn{4}{|l|}{ Threatened Someone with a Weapon } \\
\hline No & 1.49 & 3.00 & 71 \\
\hline Yes & 3.04 & 4.98 & 52 \\
\hline \multicolumn{4}{|l|}{ Assaulted/Hurt Someone with a Weapon } \\
\hline No & 0.92 & 2.04 & 66 \\
\hline Yes & 3.63 & 5.17 & 56 \\
\hline \multicolumn{4}{|l|}{$\begin{array}{l}\text { Assaulted/Hurt Someone on Calgary Transit } \\
\text { Property }\end{array}$} \\
\hline No & 1.68 & 3.89 & 85 \\
\hline Yes & 3.27 & 4.17 & 37 \\
\hline \multicolumn{4}{|l|}{ Assaulted Someone with Friends } \\
\hline No & 1.27 & 2.53 & 59 \\
\hline Yes & 2.95 & 4.90 & 64 \\
\hline \multicolumn{4}{|l|}{ With a Group of Friends, Fought with Others } \\
\hline No & 2.02 & 4.58 & 44 \\
\hline Yes & 2.22 & 3.69 & 79 \\
\hline
\end{tabular}

Sources of data: Youth Offender Interview and Police Information Management System. 
A number of mental health factors were examined to determine their relationship to the extent of reoffending following the initial interview (see Table 5). For most of these factors, there was a trend for youth who exhibited mental health disorders to have a greater number of reoffences. It should be noted that certain mental health diagnoses were present in very few youth, and thus these results should be interpreted with caution. When these 11 predictors were included in a regression analysis with the number of reoffences as the dependent variable, only a diagnosis of Attention Deficit Disorder/Attention Deficit Hyperactivity Disorder (ADD/ADHD) was significantly related to reoffending (Adjusted $R^{2}=0.04$, Beta $=0.23, t(89)=2.17, p<.05$ ). This finding indicated that youth with a confirmed diagnosis of ADD/ADHD were more likely to have a greater number of reoffences than youth without this diagnosis.

TABLE 5

\section{MEAN NUMBER OF REOFFENCES SINCE YOUTH OFFENDER INTERVIEW BY MENTAL HEALTH CHARACTERISTICS}

\begin{tabular}{|c|c|c|c|}
\hline \multirow{2}{*}{ Mental Health Characteristics } & \multicolumn{3}{|c|}{ Number of Reoffences } \\
\hline & Mean & $S D$ & $n$ \\
\hline $\begin{array}{l}\text { Ever Had a Psychological Assessment } \\
\text { No } \\
\text { Yes }\end{array}$ & $\begin{array}{l}2.51 \\
2.35\end{array}$ & $\begin{array}{l}4.63 \\
3.68\end{array}$ & $\begin{array}{l}47 \\
48\end{array}$ \\
\hline $\begin{array}{l}\text { Ever Received Counselling } \\
\text { No } \\
\text { Yes }\end{array}$ & $\begin{array}{l}2.13 \\
2.49 \\
\end{array}$ & $\begin{array}{l}4.45 \\
4.13 \\
\end{array}$ & $\begin{array}{l}15 \\
80 \\
\end{array}$ \\
\hline $\begin{array}{l}\text { Diagnosis of Mental Health Problems } \\
\text { No } \\
\text { Yes }\end{array}$ & $\begin{array}{l}2.20 \\
2.61 \\
\end{array}$ & $\begin{array}{l}3.94 \\
4.34 \\
\end{array}$ & $\begin{array}{l}46 \\
56 \\
\end{array}$ \\
\hline $\begin{array}{l}\text { Depression } \\
\text { No } \\
\text { Yes }\end{array}$ & $\begin{array}{l}2.80 \\
1.63\end{array}$ & $\begin{array}{l}3.96 \\
4.87\end{array}$ & $\begin{array}{l}74 \\
24\end{array}$ \\
\hline $\begin{array}{l}\text { Learning Disability } \\
\text { No } \\
\text { Yes }\end{array}$ & $\begin{array}{l}2.41 \\
3.15\end{array}$ & $\begin{array}{l}4.34 \\
3.26\end{array}$ & $\begin{array}{l}85 \\
13\end{array}$ \\
\hline $\begin{array}{l}\text { Attention Deficit Disorder/Attention Deficit } \\
\text { Hyperactivity Disorder } \\
\text { No } \\
\text { Yes }\end{array}$ & $\begin{array}{l}1.79 \\
3.75 \\
\end{array}$ & $\begin{array}{l}3.54 \\
4.98 \\
\end{array}$ & $\begin{array}{l}62 \\
36\end{array}$ \\
\hline $\begin{array}{l}\text { Conduct Disorder } \\
\text { No } \\
\text { Yes }\end{array}$ & $\begin{array}{l}1.99 \\
3.65\end{array}$ & $\begin{array}{l}3.60 \\
5.17\end{array}$ & $\begin{array}{l}67 \\
31\end{array}$ \\
\hline
\end{tabular}

Canadian Research Perspectives for Youth at Risk for Serious and

Violent Offending: Implications for Crime Prevention Policies and Practices 


\begin{tabular}{|c|c|c|c|}
\hline $\begin{array}{l}\text { Fetal Alcohol Spectrum Disorder } \\
\text { No } \\
\text { Yes }\end{array}$ & $\begin{array}{l}2.42 \\
4.20\end{array}$ & $\begin{array}{l}4.20 \\
4.38\end{array}$ & $\begin{array}{r}93 \\
5\end{array}$ \\
\hline $\begin{array}{l}\text { Anger Issues } \\
\text { No } \\
\text { Yes }\end{array}$ & $\begin{array}{l}2.74 \\
1.50\end{array}$ & $\begin{array}{l}4.44 \\
2.83\end{array}$ & $\begin{array}{l}80 \\
18\end{array}$ \\
\hline $\begin{array}{l}\text { Post-traumatic Stress Disorder } \\
\text { No } \\
\text { Yes }\end{array}$ & $\begin{array}{l}2.40 \\
3.75\end{array}$ & $\begin{array}{l}4.25 \\
3.69\end{array}$ & $\begin{array}{r}90 \\
8\end{array}$ \\
\hline $\begin{array}{l}\text { Attachment Disorder } \\
\text { No } \\
\text { Yes } \\
\end{array}$ & $\begin{array}{l}2.53 \\
2.17 \\
\end{array}$ & $\begin{array}{l}4.19 \\
4.83 \\
\end{array}$ & $\begin{array}{r}92 \\
6 \\
\end{array}$ \\
\hline
\end{tabular}

Sources of data: Youth Probation File Review and Police Information Management System.

Family Factors Domain. Table 6 presents the factors related to family characteristics of the youth by their average number of reoffences following their initial interview. In all cases, youth with factors associated with family breakdown tended to have a greater number of reoffences following their interview than were youth who did not have these factors. However, when these seven factors were entered into a stepwise regression analysis, none of them emerged as being statistically significant predictors with the extent of reoffending behaviour.

\section{TABLE 6}

\section{MEAN NUMBER OF REOFFENCES SINCE YOUTH OFFENDER INTERVIEW BY FAMILY CHARACTERISTICS}

\begin{tabular}{|l|c|c|c||}
\hline \multicolumn{1}{|c|}{ Family Characteristics } & \multicolumn{2}{|c||}{ Number of Reoffences } \\
\cline { 2 - 4 } & Mean & SD & n \\
\hline Marital Status of Parents & & & 37 \\
$\quad$ Married & 0.89 & 2.01 & 85 \\
Other $^{\text {a }}$ & 2.72 & 4.54 & \\
\hline Current Living Arrangements at Time of $_{\text {Interview }}$ & & \\
Both parents & 0.71 & 1.80 & 34 \\
Other & 2.70 & 4.48 & 89 \\
\hline History of Family Violence/Neglect & & & \\
No & 1.70 & 2.98 & 37 \\
Yes & 2.90 & 4.72 & 58 \\
\hline Contact with Child Welfare & & & \\
No & 1.04 & 2.99 & 56 \\
Yes & 3.07 & 4.52 & 67 \\
\hline
\end{tabular}

Canadian Research Perspectives for Youth at Risk for Serious and 
International Journal of Child, Youth and Family Studies (2011) 2.1: 172-196

\begin{tabular}{|c|c|c|c|}
\hline $\begin{array}{l}\text { History of Foster Care } \\
\text { No } \\
\text { Yes }\end{array}$ & $\begin{array}{l}1.51 \\
3.82 \\
\end{array}$ & $\begin{array}{l}3.17 \\
5.36 \\
\end{array}$ & $\begin{array}{l}89 \\
34 \\
\end{array}$ \\
\hline $\begin{array}{l}\text { History of Residence in Group Home } \\
\text { No } \\
\text { Yes }\end{array}$ & $\begin{array}{l}1.41 \\
3.15 \\
\end{array}$ & $\begin{array}{l}3.25 \\
4.73 \\
\end{array}$ & $\begin{array}{l}71 \\
52 \\
\end{array}$ \\
\hline $\begin{array}{l}\text { Ever Run Away from Home } \\
\text { No } \\
\text { Yes } \\
\end{array}$ & $\begin{array}{l}1.49 \\
2.55 \\
\end{array}$ & $\begin{array}{l}3.61 \\
4.22 \\
\end{array}$ & $\begin{array}{l}47 \\
76 \\
\end{array}$ \\
\hline
\end{tabular}

a "Other" includes never married/common law $(n=32)$, separated $(n=11)$, divorced $(n=32)$, and widowed $(n=10)$.

b "Other" includes one parent/siblings $(n=54)$, extended family $(n=4)$, foster/group home $(n=$ $10)$, independent/partner $(n=7)$, incarcerated $(n=12)$, and other $(n=2)$.

Sources of data: Youth Offender Interview, Youth Probation File Review and Police Information Management System.

Peer Group Factors Domain. Several factors were identified as related to the youths' leisure time and peer group activities, and their relationship with reoffending behaviour is presented in Table 7. Youth who were not involved in organized activities with adult leadership such as sports, clubs and groups, and lessons exhibited a greater amount of reoffending following their interview than youth who were involved in such activities. In addition, youth who stated that most of their friends were older than themselves, that their friends belonged to a gang, and they had ever been a gang member themselves tended to have a greater frequency of reoffending. When these seven predictor variables were entered into a stepwise regression analysis, the only factor that was a significant predictor of extent of reoffending was whether their friends belonged to a gang (Adjusted $R^{2}=0.03$, Beta $=0.19, t(115)=2.10, p<.05$ ). This finding indicated that youth who stated that some of their friends belonged to a gang had a higher average number of reoffences than youth whose friends were not gang members.

TABLE 7

MEAN NUMBER OF REOFFENCES SINCE YOUTH OFFENDER INTERVIEW BY LEISURE TIME ACTIVITIES AND GANG INVOLVEMENT

\begin{tabular}{|c|c|c|c|}
\hline \multirow{2}{*}{ Activities } & \multicolumn{3}{|c|}{ Number of Reoffences } \\
\hline & Mean & $S D$ & $n$ \\
\hline $\begin{array}{l}\text { Organized Activities } \\
\text { No } \\
\text { Yes }\end{array}$ & $\begin{array}{l}2.43 \\
1.54\end{array}$ & $\begin{array}{l}4.13 \\
3.73\end{array}$ & $\begin{array}{l}84 \\
39\end{array}$ \\
\hline $\begin{array}{l}\text { Sports with Adult Coaching } \\
\text { No } \\
\text { Yes }\end{array}$ & $\begin{array}{l}2.35 \\
1.29 \\
\end{array}$ & $\begin{array}{l}4.20 \\
3.36 \\
\end{array}$ & $\begin{array}{l}99 \\
24 \\
\end{array}$ \\
\hline
\end{tabular}

Canadian Research Perspectives for Youth at Risk for Serious and 
International Journal of Child, Youth and Family Studies (2011) 2.1: 172-196

\begin{tabular}{|c|c|c|c|}
\hline $\begin{array}{l}\text { Clubs/Groups with Adult Leadership } \\
\text { No } \\
\text { Yes }\end{array}$ & $\begin{array}{l}2.28 \\
0.60\end{array}$ & $\begin{array}{l}4.15 \\
1.00\end{array}$ & $\begin{array}{r}113 \\
10\end{array}$ \\
\hline $\begin{array}{l}\text { Lessons in Dance, Music, Hobbies, Other Non- } \\
\text { sport Activities } \\
\text { No } \\
\text { Yes }\end{array}$ & $\begin{array}{l}2.33 \\
0.10\end{array}$ & $\begin{array}{l}4.14 \\
0.32\end{array}$ & $\begin{array}{r}113 \\
10\end{array}$ \\
\hline $\begin{array}{l}\text { Age of Closest Friends } \\
\text { Younger/Same Age } \\
\text { Older }\end{array}$ & $\begin{array}{l}1.90 \\
2.97 \\
\end{array}$ & $\begin{array}{l}3.87 \\
4.51 \\
\end{array}$ & $\begin{array}{l}91 \\
30 \\
\end{array}$ \\
\hline $\begin{array}{l}\text { Friends Belong to a Gang } \\
\text { No } \\
\text { Yes }\end{array}$ & $\begin{array}{l}1.53 \\
2.91 \\
\end{array}$ & $\begin{array}{l}3.32 \\
4.70 \\
\end{array}$ & $\begin{array}{l}66 \\
54 \\
\end{array}$ \\
\hline $\begin{array}{l}\text { Ever Been a Member of a Gang } \\
\text { No } \\
\text { Yes }\end{array}$ & $\begin{array}{l}1.63 \\
2.85\end{array}$ & $\begin{array}{l}3.48 \\
4.65\end{array}$ & $\begin{array}{l}79 \\
41\end{array}$ \\
\hline
\end{tabular}

Sources of data: Youth Offender Interview and Police Information Management System.

School Factors Domain. Table 8 presents the school-related characteristics of youth by their average number of reoffences following their initial interview. In most cases, youth with factors related to problems at school had a higher average number of reoffences than youth who did not have these factors. However, when these six predictors were entered into a stepwise regression analysis with the number of reoffences as the dependent measure, none of them emerged as significant predictors of the extent of reoffending behaviour.

TABLE 8

MEAN NUMBER OF REOFFENCES SINCE YOUTH OFFENDER INTERVIEW BY SCHOOL-RELATED CHARACTERISTICS

\begin{tabular}{|l|c|c|c||}
\hline \multicolumn{1}{|c|}{ School Characteristics } & \multicolumn{2}{|c|}{ Number of Reoffences } \\
\cline { 2 - 4 } & Mean & SD & n \\
\hline \hline Considered Dropping Out of School $^{\mathrm{a}}$ & & & 37 \\
No & 1.89 & 3.74 & 50 \\
Yes & 2.60 & 4.52 & \\
\hline Ever Been Suspended from School $^{\mathrm{a}}$ & & & 23 \\
No & 0.91 & 2.13 & 64 \\
Yes & 2.94 & 4.87 & \\
Ever Been Bullied in School & & & 68 \\
No & 2.56 & 4.61 & 55 \\
Yes & 1.64 & 3.11 & \\
\hline
\end{tabular}

Canadian Research Perspectives for Youth at Risk for Serious and

Violent Offending: Implications for Crime Prevention Policies and Practices 
International Journal of Child, Youth and Family Studies (2011) 2.1: 172-196

\begin{tabular}{|l|r|r|r||}
\hline Ever Been in Fights at School & 0.60 & 1.50 & 20 \\
$\quad$ No & 2.47 & 4.29 & 102 \\
Yes & & & 72 \\
\hline Ever Taken a Weapon to School & 1.49 & 3.24 & 51 \\
$\quad$ No & 3.08 & 4.79 & \\
Yes & & & 64 \\
\hline Gangs at School & 2.02 & 3.69 & 55 \\
No & 2.13 & 4.36 & \\
Yes
\end{tabular}

${ }^{a}$ These questions were only asked of youth who were attending school at the time of the interview.

Sources of data: Youth Offender Interview and Police Information Management System.

Community Factors Domain. Three community-related factors were identified as potential predictors of the extent of youth offending behaviour (see Table 9). Youth who reported feeling safe in their community tended to have a higher average number of reoffences than did those who reported feeling at least somewhat unsafe. There was a trend that youth who reported that they had carried a weapon in their community and that there were gangs in their community had a higher number of reoffences following their interview. When these three variables were entered into a stepwise regression analysis predicting the extent of reoffending, only the presence of gangs in the community emerged as a significant predictor (Adjusted $R^{2}=$ 0.05 , Beta $=0.23, t(119)=2.58, p<.05)$. This result indicated that youth who stated that there were gangs in their community had a higher average number of reoffences than youth who indicated that there were no gangs in their community.

TABLE 9

MEAN NUMBER OF REOFFENCES SINCE YOUTH OFFENDER INTERVIEW BY COMMUNITY-RELATED CHARACTERISTICS

\begin{tabular}{|c|c|c|c|}
\hline \multirow{2}{*}{ Community Characteristics } & \multicolumn{3}{|c|}{ Number of Reoffences } \\
\hline & Mean & $S D$ & $n$ \\
\hline $\begin{array}{l}\text { Feelings of Safety in Community } \\
\text { Sometimes unsafe/unsafe } \\
\text { Safe }\end{array}$ & $\begin{array}{l}1.52 \\
2.29\end{array}$ & $\begin{array}{l}3.40 \\
4.15\end{array}$ & $\begin{array}{r}23 \\
100\end{array}$ \\
\hline $\begin{array}{l}\text { Ever Carried Weapon in Community } \\
\text { No } \\
\text { Yes }\end{array}$ & $\begin{array}{l}1.60 \\
2.94 \\
\end{array}$ & $\begin{array}{l}3.55 \\
4.54 \\
\end{array}$ & $\begin{array}{l}73 \\
50 \\
\end{array}$ \\
\hline $\begin{array}{l}\text { Gangs in Community } \\
\text { No } \\
\text { Yes }\end{array}$ & $\begin{array}{l}1.28 \\
3.14\end{array}$ & $\begin{array}{l}2.59 \\
5.08\end{array}$ & $\begin{array}{l}64 \\
56\end{array}$ \\
\hline
\end{tabular}

Sources of data: Youth Offender Interview and Police Information Management System.

Canadian Research Perspectives for Youth at Risk for Serious and

Violent Offending: Implications for Crime Prevention Policies and Practices 
International Journal of Child, Youth and Family Studies (2011) 2.1: 172-196

\section{Discussion}

The presence of risk factors associated with reoffending was explored among a sample of 123 Calgary, Alberta youth with various degrees of involvement with the justice system. Data was obtained from life history interviews, probation file reviews, and police contact data. Factors measured the five domains consistently discussed in the literature - individual, family, peer, school, and community. A series of forward stepwise linear regression analyses were conducted using the predictors in each domain to determine whether the presence of each factor predicted greater reoffending among the sample.

First, individual factors were explored. The factors tested fell into five general categories: personal characteristics, drug- and alcohol-related behaviour, property-related delinquency, person-related delinquency, and mental health characteristics. The current study did not find any personal characteristics to be significantly related to reoffending. With regard to gender, the absence of a significant finding may be in line with recent studies demonstrating that gender is not as substantial a predictor of reoffending as it has been traditionally (Carr \& Vandiver, 2001; Haapanen et al., 2007; Howell, 2003; Jennings et al., 2010).

The analyses also examined substance use and involvement with drugs. Though a substantial proportion of those who had reoffended used drugs and alcohol, these were not found to be significantly related to reoffending in the model; however, having bought illegal drugs was found to be significant. Similarly, when self-reported property offences were examined, youth who had reported engaging in behaviours such as stealing cars, property damage, and theft tended to have a greater number of reoffences. When the predictors were examined within the regression model, having stolen a car or motorcycle was the only significant predictor. These findings are consistent with previous research suggesting that repeat offenders often commit habitual antisocial acts and have lengthy histories of behavioural concerns (e.g., Benda \& Tollett, 1999; Mullis et al., 2005). For those who are substance addicted, offending may provide the resources necessary to support the addiction. For more serious, person-related offences such as robbery or assault, those in the sample who had engaged in these behaviours tended to have more reoffences. When all the measures were entered into the regression analysis, having ever assaulted someone with a weapon was found to be a significant predictor.

This study also adds to the literature on the relationship between mental health factors and youth reoffending. Data from the first stage of this research (DeGusti, MacRae, \& Hornick, 2008) indicated that complex mental health disorders (i.e., multiple diagnoses) were common among youth more seriously involved in the justice system. This report also showed that virtually all of the youth with a diagnosis of FASD had reoffended. However, the regression model used in the current study suggested that among the many diagnoses that were tested, only $\mathrm{ADD} / \mathrm{ADHD}$ was significantly related to greater reoffending. This finding is in line with Mullis et al.'s study (2005), where $60 \%$ of their sample of chronic youth offenders were diagnosed with oppositional defiant disorder (ODD) or ADD at some point. Putnins' (2009) study assessing risk for recidivism among juvenile offenders also confirmed that ADD/ADHD is a significant risk

Canadian Research Perspectives for Youth at Risk for Serious and 
factor for an elevated risk to reoffend. Putnins (2009) points out that the symptoms of $\mathrm{ADD} / \mathrm{ADHD}$ (poor concentration, restlessness, impulsivity) overlap with low self-control, a concept posed two decades ago by Gottfredson and Hirschi (1990) to explain reoffending. However, it should be cautioned that the finding in the current study is somewhat limited by the fact that some mental health diagnoses were present in very few youth.

The regression analysis of family factors did not yield any significant predictors of reoffending. However, the analysis did demonstrate that those youth who possessed characteristics related to family breakdown, such as not living with both parents, having been involved with the child welfare system, having been in foster care or a group home, and having experienced family violence, consistently had a higher average number of reoffences. Research has consistently reported links between family violence or breakdown and reoffending among youth (Arnull et al., 2005; Carr \& Vandiver, 2001; Benda \& Tollett, 1999; Howell, 2009; MacRae et al., 2008; Mullis et al., 2005; Turner et al., 2007; Stewart et al., 2008; Ward \& Day, 2010). Increasingly, the significant impact of involvement with children's services is being discussed (Ryan, 2006; Ryan et al., 2007; Ward \& Day, 2010). A recent longitudinal study of a cohort of over 50,000 children in British Columbia conducted by the British Columbia Representative for Children and Youth and the Provincial Health Officer (2009) revealed that "a higher proportion of children and youth in care in B.C. become involved with the youth justice system (35.5\%) than graduate from high school (24.5\%)" (p. 7).

Despite being a distinguishing family characteristic in the original descriptive study (MacRae et al., 2008), as well as being a common risk factor reported in previous literature (Arnull et al., 2005; Stewart et al., 2008; Ward \& Day, 2010) family violence and neglect were not significant factors associated with reoffending in the present study. The data on family violence and neglect were limited in that they were not collected by self-report, but rather from the probation file review. Though probation files often report this type of information, it is possible that violence or neglect may have occurred that was not recorded in the probation file. Further, youth who have longer histories with youth probation tended to have more background information and more extensive probation files. Therefore, any youth with shorter probation histories (e.g., one-time offenders) may not have this detailed type of information recorded in their file. Additionally, the sample of Gateway youth did not have probation file information and therefore were not included in the analysis of family violence. Thus, the data on family violence and neglect may not be a true reflection of its incidence among the study sample. Overall, though the current analysis did not demonstrate any significant predictors, the findings still point to an important story regarding the impact of family disruption.

The descriptive findings related to social and peer factors were also consistent with the literature. Youth who were not involved in structured activities tended to have approximately twice the average number of reoffences as those who were, pointing to the protective influence of organized activities such as clubs, sports, or lessons. Examination of peer characteristics and gang involvement also revealed that youth who have older friends, friends who belong to a gang, and friends who had themselves ever been a gang member had higher average numbers of reoffences. Having friends who belong to a gang was the only peer factor found to be significant 
International Journal of Child, Youth and Family Studies (2011) 2.1: 172-196

in the model. This is consistent with a number of studies examining the impact of negative peer affiliation and gang involvement on reoffending (Benda \& Tollett, 1999; Howell, 2003; Johnson et al., 2004; Trulson et al., 2005). It is important to note that the factors in the individual, family, school, peer, and community domains that place a youth at risk for gang involvement are often the same factors that place a youth at risk for persistent reoffending, and that these factors often have a cumulative and interactive effect.

The regression model on school factors also did not yield any significant predictors. However, the descriptive analyses demonstrated that youth who have had problems at school with truancy, suspensions, getting into fights, taking a weapon, and have considered dropping out of school tended to have a higher average number of reoffences than those who did not. This is consistent with the literature suggesting that school difficulties are often associated with criminal behaviour among youth (Arnull et al., 2005; Mullis et al., 2005). Further, the significance of a diagnosis of ADD/ADHD in relation to reoffending would also have an impact on school performance and success; this finding was confirmed by Mullis et al. (2005). These notable behavioural and learning concerns speak to the importance of the school as a point of prevention and early intervention.

Finally, factors related to the youths' community were examined in relation to reoffending. Feelings of safety in the community, presence of gangs, and carrying a weapon in the community were tested, with the presence of gangs emerging as a significant predictor. However, the literature suggests that protective factors such as parental supervision and discipline may buffer the effects of community risk factors (Patterson et al., 1992). Turner and colleagues (2007) suggest that community factors often interact with other factors to place a youth at risk for reoffending. Recent work by Grunwald and colleagues (2009) demonstrates that neighbourhood factors have a differential influence on the type of reoffending (e.g., drug, property, violent). Though the available data were not sufficient to test these effects, the impact of the community environment was demonstrated.

\section{Limitations and Future Directions}

The analyses yielded a number of important observations among all five risk factor domains. However, though a number of studies (Chung et al., 2002; Lipsey \& Derzon, 1998; Turner et al., 2007) have pointed to the importance of examining combinations and interactions of factors, and in particular, their developmental influence, the current data did not allow for a developmental analysis. Recent U.S. studies (Haapanen et al., 2007; Howell, 2003; Mullis et al., 2005; Ryan et al., 2007) have closely examined the developmental stages at which certain characteristics begin to manifest or at which significant critical events occur (e.g., family breakdown, family violence). Findings such as these can promote more targeted and effective prevention and intervention programs. British Columbia’s recent longitudinal study of a cohort of over 50,000 youth has demonstrated the value of this approach (British Columbia Representative for Children and Youth \& Provincial Health Officer, 2009), as has the study by Day and colleagues (2008) of the criminal trajectories of 378 male youth offenders in Toronto. 
Future Canadian studies with this focus would contribute significantly to this growing body of literature.

The longitudinal nature of this study provides a valuable contribution to the Canadian literature. However, it is important to note that the follow-up data were limiting in that only reoffending data were collected. Since the youth were not re-interviewed, their individual, family, peer, community, and school situations may have changed, thereby impacting their offending behaviour. However, by collecting longitudinal reoffending data, this study was able to illustrate factors that are important for stakeholders to address, permitting more targeted prevention efforts and more effective interventions for youth already involved in the justice system. Given that youth who reoffend manifest risk factors in a number of domains of their lives, schools, families, community agencies, and children's services are in a unique position to identify youth at risk and provide the opportunity to intervene early.

This study was also limited by the heterogeneity of the subjects, who ranged from being diverted from the formal court process through extrajudicial measures to being serious habitual offenders. The entire sample was combined for the analysis, which was necessary given the relatively small total sample size $(N=123)$. Though combining the groups increased the statistical power and allowed for greater variability in reoffending, heterogeneity of the group may have impacted the confidence interval that was used in reporting results in the study. Further, since the original study focused on comparison among four distinct groups, ranging from youth diverted to extrajudicial measures, one-time offenders, chronic offenders (having five or more substantive incidents), and serious habitual offenders, youth who fell between one-time and chronic offenders were not studied. This may also have had an impact on the analysis. Future studies of reoffending would benefit from a larger, more inclusive sample.

\section{Conclusion}

The current study explored risk factors associated with reoffending among a sample of youth offenders in Calgary, Alberta. When considered together, these factors paint a picture of complex and disadvantaged youth who lack structure, support, and stability, and who require specialized, targeted interventions. Youth reoffenders, particularly those who do so persistently, consume a disproportionate amount of youth justice system resources and have a significant impact on their victims. In an era when the Youth Criminal Justice Act and its effectiveness are under scrutiny, it is important to establish a comprehensive understanding of the youth who are impacted, or potentially impacted, by this legislation in an effort to ensure that well-informed policy and practice decisions are made. 
International Journal of Child, Youth and Family Studies (2011) 2.1: 172-196

\section{References}

Alberta Crime Reduction and Safe Communities Task Force. (2007). Keeping communities safe: Report and recommendations. Edmonton: Government of Alberta.

Arnull, E., Eagle, S., Gammampila, A., Archer, D., Johnson, V., Miller, K., et al. (2005). Persistent young offenders: A retrospective study. London: Youth Justice Board for England and Wales.

Bala, N., Carrington, P., \& Roberts, J. (2009). Evaluating the Youth Criminal Justice Act after five years: A qualified success. Canadian Journal of Criminology and Criminal Justice, 51(2), 131-167.

Benda, B. B., \& Tollett, C. L. (1999). A study of recidivism of serious and persistent offenders among adolescents. Journal of Criminal Justice, 27(2), 111-126.

British Columbia Representative for Children and Youth \& British Columbia Provincial Health Officer. (2009). Kids, crime and care - Health and well-being of children in care: Youth justice experiences and outcomes. Victoria: Government of British Columbia.

Carr, M. B., \& Vandiver, T. A. (2001). Risk and protective factors among youth offenders. Adolescence, 36(143), 409-426.

Chung, I., Hill, K. G., Hawkins, J. D., Gilchrist, L. D., \& Nagin, D. S. (2002). Childhood predictors of offence trajectories. Journal of Research in Crime and Delinquency, 39(1), 60-90.

Day, D. M., Bev, I., Theodor, F., Rosenthal, J. S., \& Duchesne, T. (2008). Change and continuity in criminal offending: Criminal trajectories of the "Toronto" sample. Toronto: Ontario Ministry of Children and Youth Services.

DeGusti, B. (2008). The impact of the Youth Criminal Justice Act on case flow in Alberta and system response in Calgary. Calgary, AB: Canadian Research Institute for Law and the Family

DeGusti, B., MacRae, L., \& Hornick, J. P. (2008). An in-depth examination of school investment and extracurricular activities by a youth offender cohort. Calgary, AB: Canadian Research Institute for Law and the Family.

Denning, R., \& Homel, R. (2008). Predicting recidivism in juvenile offenders on communitybased orders: The impact of risk factors and service delivery. Journal of Offender Rehabilitation, 46(3/4), 189-215. 
International Journal of Child, Youth and Family Studies (2011) 2.1: 172-196

Department of Justice Canada. (n.d.). The Youth Criminal Justice Act: Summary and background. Retrieved April 16, 2008, from http://canada.justice.gc.ca/eng/pi/yj-jj/ycjalsjpa/back-hist.html.

Gottfredson, M. R., \& Hirschi, T. (1990). A general theory of crime. Stanford, CA: Stanford University Press.

Grunwald, H. E., Lockwood, B., Harris, P. W., \& Mennis, J. (2009). Influences of neighborhood context, individual history and parenting behaviour on recidivism among juvenile offenders. Journal of Youth and Adolescence, 39(9), 1067-1079.

Haapanen, R., Britton, L., \& Croisdale, T. (2007). Persistent criminality and career length. Crime \& Delinquency, 53(1), 133-155.

Howell, J. C. (2003). Diffusing research into practice using the comprehensive strategy for serious, violent, and chronic juvenile offenders. Youth Violence and Juvenile Justice, 1(3), 219-245.

Howell, J. C. (2009). Preventing and reducing juvenile delinquency: A comprehensive framework (2nd ed.). Thousand Oaks, CA: Sage Publications Inc.

Jennings, W. G., Maldonado-Molina, M. M., \& Komro, K. K. (2010). Sex similarities/differences in trajectories of delinquency among urban Chicago youth: The role of delinquent peers. American Journal of Criminal Justice, 35(1-2), 56-75.

Johnson, L., Simons, R., \& Conger, R. (2004). Criminal justice system involvement and continuity of youth crime. Youth \& Society, 36(1), 3-29.

Lemmon, J. H. (2006). The effects of maltreatment recurrence and child welfare services on dimensions of delinquency. Criminal Justice Review, 31(1), 5-32.

Lipsey, M. W., \& Derzon, J. H. (1998). Predictors of violence or serious delinquency in adolescence and early adulthood: A synthesis of longitudinal research. In R. Loeber \& D. P. Farrington (Eds.), Serious and violent juvenile offenders: Risk factors and successful interventions (pp. 86-105). Thousand Oaks, CA: Sage Publications.

Livingston, M., Stewart, A., Allard, T., \& Ogilvie, J. (2008). Understanding juvenile offending trajectories. The Australian and New Zealand Journal of Criminology, 41(3), 345-363.

MacRae, L. D., Bertrand, L. D., Paetsch, J. J., \& Hornick, J. P. (2008). A profile of youth offenders in Calgary: An interim report. Calgary, AB: Canadian Research Institute for Law and the Family.

Canadian Research Perspectives for Youth at Risk for Serious and 
International Journal of Child, Youth and Family Studies (2011) 2.1: 172-196

MacRae, L. D., Bertrand, L. D., Paetsch, J. J., Hornick, J. P. \& DeGusti, B. (2009). A study of youth reoffending in Calgary. Calgary, AB: Canadian Research Institute for Law and the Family.

McMurtry, R., \& Curling, A. (2008). The review of the roots of youth violence. Toronto, ON: Queen's Printer.

Mullis, R. L., Mullis, A. K., Cornille, T. A., Kershaw, M. A., Beckerman, A., \& Perkins, D. (2005). Young chronic offenders: A case study of contextual and intervention characteristics. Youth Violence and Juvenile Justice, 3(2), 133-150.

Nunn, M. D. (2006). Spiralling out of control: Lessons learned from a boy in trouble (Report of the Nunn Commission of Inquiry). Halifax: Province of Nova Scotia.

Patterson, G. R., Reid, J. B., \& Dishion, T. J. (1992). Antisocial boys: A social interactional approach. Eugene, OR: Castalia.

Putnins, A. (2005). Assessing recidivism risk factors among young offenders. The Australian and New Zealand Journal of Criminology, 38(3), 324-339.

Ryan, J. P. (2006). Dependent youth in juvenile justice: Do positive peer culture programs work for victims of child maltreatment? Research on Social Work Practice, 16(5), 511-519.

Ryan, J. P., Hernandez, P. M., \& Herz, D. (2007). Developmental trajectories of offending for male adolescents leaving foster care. Social Work Research, 31(2), 83-93.

Sharkey, J. D., Furlong, M. J., Jimerson, S. R., \& O’Brien, K. M. (2003). Evaluating the utility of risk assessment to predict recidivism among male and female adolescents. Education and Treatment of Children, 26(4), 467-494.

Stewart, A., Livingston, M., \& Dennison, S. (2008). Transitions and turning points: Examining the links between child maltreatment and juvenile offending. Child Abuse \& Neglect, 32(1), 51-66.

Trulson, C. R., Marquart, J. W., Mullings, J. L., \& Caeti, T. J. (2005). In between adolescence and adulthood: Recidivism outcomes of a cohort of state delinquents. Youth Violence and Juvenile Justice, 3(4), 355-387.

Turner, M. G., Hartman, J. L., \& Bishop, D. M. (2007). The effects of prenatal problems, family functioning, and neighborhood disadvantage in predicting life-course-persistent offending. Criminal Justice and Behavior, 34(10), 1241-1261. 
International Journal of Child, Youth and Family Studies (2011) 2.1: 172-196

Tyler, K. A., Johnson, K. A., \& Brownridge, D. A. (2008). A longitudinal study of the effects of child maltreatment on later outcomes among high-risk adolescents. Journal of Youth and Adolescence, 37(5), 506-521.

Ward, A. K., \& Day, D. M. (2010). Criminal predictors and protective factors in a sample of young offenders: Relationship to offending trajectories. Toronto: Ministry of Children and Youth Services. 